\title{
In vitro Micropropagation and Cytomorphological Evaluation of Centella asiatica (L.) Urban (Mandukparni) from Himachal Pradesh, India - An Endemic, Endangered and Threatened Herb
}

\author{
Gurwinder Singh, Bhawandeep Kaur, Navdeep Sharma ${ }^{1}$, Anisha \\ Bano $^{1}$, Sanjeev Kumar ${ }^{1}$, Harcharan S. Dhaliwal ${ }^{1}$ and Vivek \\ Sharma ${ }^{1 *}$
}

Guru Granth Sahib World University, Fatehgarh Sahib-140406 (Punjab), India

Key words: Centella asiatica, Indian pennywort, Memory enhancer, Cytomorphotypes

\begin{abstract}
The present research work reports the cytomorphological evaluation and an efficient protocol for in vitro micropropagation of an endemic, endangered and threatened herb Centella asiatica (L.) Urban (Mandukparni) from Himachal Pradesh, India. Plant species is a potent memory enhancer, antidiabetic, antioxidant, antimutagenic, anticancerous and also reported to have cardiovascular properties and used to cure chronic hepatitis disorders. Eight morphometric characters for each 10 different accessions were extensively studied, but no new morphotype was reported. As per the cytology, the present report $(2 n=18)$ confirmed the earlier chromosome counts from India and abroad. As there is an important need to preserve this plant species and to make it available all over the year to pharmaceutical industries without causing loss of germplasm from the wild region, efficient in vitro micropropagation protocol through nodal explant has been developed. As per the results, the highest percentage of multiple shoot induction was 90.20 showing average 16.3 number of shoots on the medium augmented with $2.0 \mathrm{mg} / \mathrm{l} \mathrm{BAP}+0.5 \mathrm{mg} / \mathrm{l} \mathrm{Kn}$. Whereas, the combined concentration of $1.0 \mathrm{mg} / \mathrm{l} \mathrm{NAA}+1.0 \mathrm{mg} / \mathrm{l} \mathrm{IBA}$ showed highest $92.2 \%$ root induction with average 16.5 number of roots per shoot. The survival rate of these plantlets under green house condition was $80 \%$. This protocol can be used for further regeneration and genetic transformation studies in Centella
\end{abstract}

*Author for correspondence: <vivek03sharma@rediffmail.com>. ${ }^{1}$ Akal School of Biotechnology, Eternal University, Baru Sahib-173101, H.P., India. 
asiatica (L.) Urban. This research communication provides first record about the cytomorphological status comprises with in vitro multiplication of C. asiatica (L.) Urban, from Himachal Pradesh.

\section{Introduction}

Centella asiatica (L.) Urban (Apiaceae) is a perennial prostrate, aromatic herb, creeping with long stolons, rooting at nodes, leaves simple, flowers pink or red, fruit ovoid. The herb distributed and found wild throughout tropical and subtropical regions or countries like Bangladesh, Nepal, India, China, Malaysia, Indonesia, Sri Lanka and South America (Satake et al. 2007, Zheng and Quin 2007). Commonly known in India as Indian pennywort, Mandukaparni, Jal Brahmi and Gotukola (Pullaiah 2006) and in Bangladesh it is well known as Thankuni (Huq 1986), herb is known as Pegagainin Malaysia, Gotukola in America, Kakikuda or Pegagan in Indonesia, Luiei Gon Gen or Tung Chain in China (Tolkha 1999). In India, this species can be found up to an altitude of 500 to $1800 \mathrm{~m}$ above sea level (Patra et al. 1998).

It is well defined by the Botanical Survey of India (BSI) that the requirement of Centella asiatica (L.) Urban plant in India is met from the natural resources/populations, leading to their gradual depletion and due to over exploitation of this herb for medicinal purposes and the absence of organized cultivation practices, this important plant species has dwindled to such a critical level that a ban on its collection from the wild has been recommended (Nayar and Sastry 1987). Because of unrestricted exploitation of this valuable natural resource, its ever increasing demand by the Indian pharmaceutical industries, limited cultivation and insufficient attempts for its replenishment, the wild stock of this medicinally important plant species has been markedly depleted and now it is listed as threatened species by the International Union for Conservation of Nature and Natural Resources (IUCN) (Pandey et al. 1993) and an endangered species (Singh 1989, Sharma and Kumar 1998). This species is also considered as endemic to Western Ghats of South India (Nayar 1996).

The substances of therapeutic interest are the saponin containing triterpene acids, asiatic acid, madecassic acid, asiaticosides as A and B (Kirtikar and Basu 1975). The plant acts as potent memory enhancer which contains glycosides as brahmoside, brahminoside, indocentelloside and leaves are rich in carotenoids, vitamin B and C (Silviya 2010). Vellaerine is the active component present in the leaves, is an oleaginous white crystalline substance considered advantageous in cognitive impairment (Bakhru 2003). Leaves extract inhibits the growth of human uterine carcinoma, human gastric carcinoma and mirine melanoma cells in vitro (Yoshida et al. 2005). Extract of whole plant is reported to have 
anticancerous activity (Yu et al. 2006). The most eminent bioactive components found in $C$. asiatica are triterpenoid glycosides, saponin glycosides and flavonoids, which are known to possess antileprotic, antifilarial, antibacterial, adaptogenic, antifeedant, antidiabetic, antiviral, antiulcer, antioxidant, antitumour and with very high memory enhancing activity along with antimutagenic, cardiovascular properties and treatment in chronic hepatitis disorders (Darnis et al. 1979, Montecchio et al. 1991, Cesarone et al. 1992, Warrier et al. 1994, Babu et al. 1995, Chakraborty et al. 1996, Srivastava et al. 1997, Shukla et al. 1999b, Yen et al. 2001, Vasantharuba et al. 2012).

The whole plant is used in anxiety, neurosis, memory enhancer, jaundice, leprosy and skin diseases. The plant is also used as antidote to cholera, against rheumatism, elephantiasis, hydrocele, in tonics, bronchitis, asthma, gastric problems, leucorrhoea, kidney troubles and dropsy. Oral administration of different extracts showed anticonvulsant activity (Sudha et al. 2002) and aqueous extract of leaves has shown wound healing activity (Patil and Mandewgade 2003). Plant is used in the therapy of fever, measles, haematemesis, epistaxis, diarrhea, dysentery, rheumatism, spasms, ulcers, tuberculosis, syphyllis, acne, allergies, convulsions, eczema, gonorrhea and jaundice (Hanida and Kapoor 1988; Hausen 1993, Inamdar et al. 1996). Plant is also used as a component in one of the drug 'Geriforte' used to cure senile pruritus (Anon. 1992). It is a brain tonic, psycho-physical regenerator and blood purifier (Jorge and Jorge 2005). Plant is rich in minerals such as calcium, magnesium, potassium, phosphorus and aluminium (Herbert et al. 1994, Brinkhaus et al. 2000). This herb used as a raw material for preparation of pharmaceuticals, dermaceuticals and aroma therapeutical products. The plant is extensively used in Indian Herbal Pharmacopoeia, German Homeopathic Pharmacopoeia, European Pharmacopoeia and the Pharmacopoeia of the People's Republic of China (Brinkhaus et al. 2000).

As per earlier cytological studies on genetic divergence among the accessions of C. asiatica (L.) Urban were restricted to India, cytotype with $(2 n=18)$ was reported by different researchers (Mitra and Datta 1967, Datta and Maiti 1968a, Sinha and Sinha 1978, Ahmad and Koul 1980, Prasad and Janakiammal 1985, Subramanian 1986, Krishnanappa and Basappa 1988, Hamal and Koul 1989, Das and Mallick 1991, Trivedi and Trivedi 1992). The intraspecific polyploidy within the species is well reported from India and other parts of the world such as: $(22+$ 1 - 2B) by Joshi and Raghuvanshi (1970) and $(2 n=22)$ by Raghuvanshi and Joshi (1968). Therefore, there is great need to check the ploidy level of this estonishing herb and to establish a link between cytomorphological aspects with phytobiochemical relatedness. 
In recent years, in-vitro culture techniques has been gaining popularity due to mass multiplication and germplasm conservation of rare, endangered and threatened medicinal plants (Sahoo and Chand 1998, Prakash et al. 1999, Rao 2004). As we know that tissue culture techniques can play a significant role in the rapid multiplication of the elite genotypes or clones and germplasm conservation of $C$. asiatica. There are a number of research publications previously reported on in-vitro regeneration of C. asiatica (L.) Urban through callus culture from leaf explants (Patra et al. 1998, Banerjee et al. 1999, Naidu et al. 2014), from stem node explants (Hossain et al. 2000), stem segments (Patra et al. 1998), through somatic embryogenesis (Martin 2004), from nodal segments (Karthikeyan et al. 2009), regeneration of plant from non-embryonic cell lines (Bibi et al. 2011), from shoot tips explant (Tiwari et al. 2000; Nath and Alak 2003, Rahman et al. 2008, Moghaddam et al. 2011, Chaturvedi et al. 2013). Nowaday, the common method employed for the micropropagation involves the propagation of shoots via a solid or semi-solid system. Such systems have successfully contributed to improve multiplication yield and more important in improving productivity and reducing the time taken for multiplication of plant. Therefore, it is important to develop an efficient micropropagation technique for this most important herb. Although extensive research has already been done on this herb, but present communication, reports a reproducible and rapid method for in vitro multiplication of $C$. asiatica through high frequency axillary shoot proliferation from nodal explants followed by successful establishment of regenerated plants in soil. In here we describe a protocol for high frequency plant regeneration from nodal explants of C. asiatica (L.) Urban for the first time from Himachal Pradesh (India).

Even though the genus is medicinally so important, it has failed to attract the attentions of the researchers regarding the combined and comparative study of both cytomorphological and micropropagation parameters on different populations of $C$. asiatica from Himachal Pradesh. Therefore, as a part of our investigation on selected medicinal and aromatic plants from North India, this research communication is a pioneer attempt to provide first record about the cytomorphological status comprises with in vitro multiplication of $C$. asiatica (L.) Urban, a naturally grown medicinally important plant species from Himachal Pradesh, which were previously undescribed from this study region.

\section{Materials and Methods}

Plant materials for cytomorphological studies were collected from wild region of Sirmour District (Himachal Pradesh) and cultivated in agricultural experimental farms and for in vitro micropropagation of Centella asiatica (L.) Urban, cultivated 
accessions were collected during the months of June-July, 2014 from agricultural experimental farms and analysed in Biotechnology Laboratory of Eternal University, Baru Sahib, Himachal Pradesh (India). Plants specimens were identified by the Department of Botany, the Punjabi University, Patiala (Punjab), India.

On the basis of eight morphometric characters, namely plant height $(\mathrm{cm})$, leaf colour, leaf size $(\mathrm{cm})$, number of leaves/branch, number of branches/node, length of stolon between nodes, flower colour, primary root length $(\mathrm{cm})$, root diameter (cm) $(2 \mathrm{~cm}$ below base) on 10 plants were extensively studied from the study area for each accession of $C$. asiatica and the average results were taken into consideration to find out new morphotypes (Table 1).

Immature floral buds were collected for each accession and fixed in Carnoy's fixative for $24 \mathrm{hrs}$ and preserved in $95 \%$ alcohol at $4^{\circ} \mathrm{C}$ for further use. For meiotic studies smear was made using standard aceto-carmine technique to analyze cytological variability. A number of slides were carefully examined for cytological analysis, chromosome counts were made and abnormalities were recorded in each population. Pollen analysis was made by mounting pollen grains from mature flowers in 50\% glycerol-acetocarmine and by taking well filled pollen grains with stained nuclei as apparently viable while shriveled and unstained pollen grains were taken as sterile. The photomicrographs of the chromosomes count were made from permanent and freshly prepared slides with the help of Leica Qwin Digital Imaging System.

Nodal explants/shoot tips were collected from the young sprouts of the stock plants and thoroughly washed under the running tap water for $30 \mathrm{~min}$ and treated with 10\% (v/v) Teepol (Himedia, Ltd. India) for $15 \mathrm{~min}$ and followed by repeated rinsing with running tap water for $10 \mathrm{~min}$. The explants were washed thrice with double distilled water and further sterilization was done under aseptic conditions in a Laminar Airflow Hood/Chamber (Popular Traders, India). The explants were surface sterilized with $0.1 \%(\mathrm{w} / \mathrm{v}) \mathrm{HgCl}_{2}$ for $8 \mathrm{~min}$ and thoroughly washed with sterile/autoclaved double distilled water several times to remove traces of sterilant $\left(\mathrm{HgCl}_{2}\right)$ before inoculation.

The shoot tips were cut into appropriate size and cultured on MS basal medium containing 3\% (w/v) sucrose in all experiments. The $\mathrm{pH}$ of the medium was adjusted to 5.8 prior to autoclaving and addition of $0.8 \%(\mathrm{w} / \mathrm{v})$ agar. The molten medium was dispensed in $15 \mathrm{ml}$ aliquots into culture tubes $(25 \times 150 \mathrm{~mm})$ and capped with non-absorbent cotton plugs. Along with that $50 \mathrm{ml}$ molten medium was also dispensed in different glass jam jars $(400 \mathrm{ml})$. The medium was autoclaved at $1.1 \mathrm{Kg} / \mathrm{cm}^{2}$ pressure and $121^{\circ} \mathrm{C}$ for $15 \mathrm{~min}$. The cultures were 


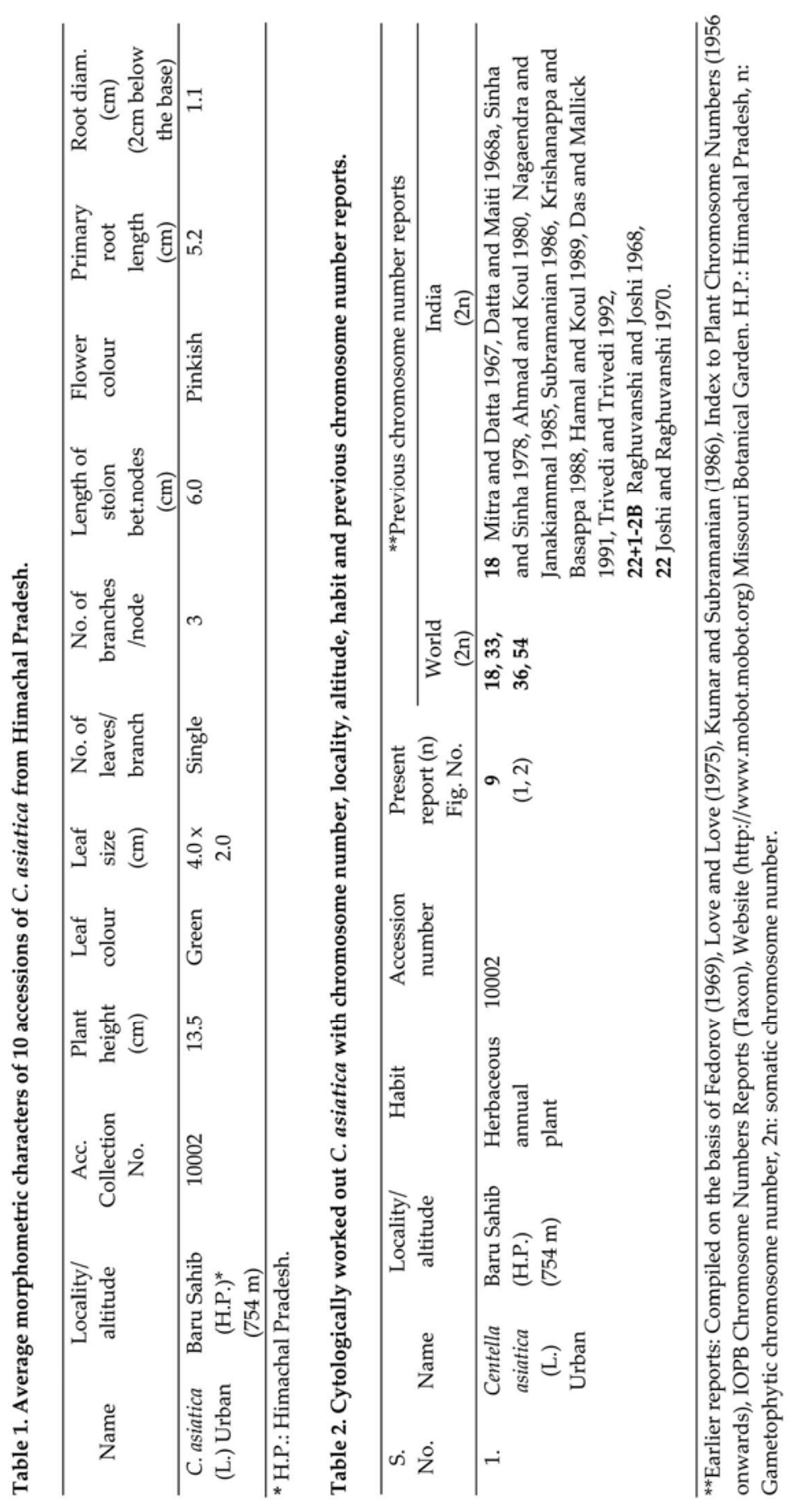


incubated in the culture room maintained at $25 \pm 2^{\circ} \mathrm{C}$ and $50-70 \% \mathrm{RH}$ under a photoperiod of $16 \mathrm{hrs}$ at 3000 lux light intensity provided by cool white florescent tubes (Philips Ltd. India).

For shoot proliferation MS supplemented with various concentrations of plant growth regulators, different concentrations of BAP 1, 2, $3 \mathrm{mg} / \mathrm{l}$ combined with fixed concentration of $\mathrm{Kn}(0.5 \mathrm{mg} / \mathrm{l})$ were used for culture initiation and multiplication of shoots. In addition, different concentrations of $\mathrm{Kn}(1,2,3 \mathrm{mg} / \mathrm{l})$ and BAP $(1,2,3 \mathrm{mg} / \mathrm{l})$ were also used for shoot induction. All the cultures were transferred to the fresh medium after 2 - 3 weeks. The mean number of shoots and lengths were evaluated after 4 weeks of inoculation.

In vitro raised shoots $(3-6 \mathrm{~cm})$ were excised and transferred to full strength MS containing 3\% (w/v) sucrose solidified with $0.8 \%(\mathrm{w} / \mathrm{v})$ agar. The medium was further supplemented with different concentrations of NAA and IBA $(1,2,3$ $\mathrm{mg} / \mathrm{l})$ and combined concentration of both NAA and IBA $(0.5+0.5,1.0+1.0,1.5$ $+1.5 \mathrm{mg} / \mathrm{l})$. Data of the number of roots were recorded after four weeks.

Well-developed rooted plantlets were removed carefully from the culture vessels, washed gently under running tap water to remove the remains of agar and transferred to pots containing sterilized mixture of sand, soil and farmyard manure in the ratio of $1: 1: 1$. The potted plantlets were kept under transparent polythene sheets for 2 weeks to ensure high humidity and then kept in open diffused light for hardening. After 20 days the surviving plants were transferred to pots containing garden soil and maintained in the greenhouse for acclimation.

\section{Results and Discussion}

We have extensively studied eight morphometric characters namely: Plant height; leaf colour, leaf size, number of leaves/branch, number of branches/node, length of stolon between nodes, flower colour, primary root length $(\mathrm{cm})$, root diameter ( $2 \mathrm{~cm}$ below base) for each 10 different accessions of C. asiatica, this extensive screening revealed that there is no new morphotype reported on the basis of study conducted. For all the accessions the average plant height $(13.5 \mathrm{~cm})$ was recorded, the leaf color was green in all the accessions, leaves are simple, orbicular-reniform, puberulous and single per branch. We have recorded that every node has an average of 3 branches/nodes, well established rooting was recorded at every node with average primary root length $(5.2 \mathrm{~cm})$ along with root diameter $(1.1 \mathrm{~cm})$, the average length of creeping long stolons between two nodes $(6.0 \mathrm{~cm})$ (Figs A, B and C), pinkish colored flowers in axillary fasciculate umbels were recorded in all the accessions (Table 1.). 
The present meiotic study was made in wild population collected from Baru Sahib (H.P.) region and cultivated in the Departmental greenhouse. The study revealed the presence of 9 bivalents in all the PMCs at M-I (Figs D and E). PMCs at A-I showed 9 chromosomes at each pole (Fig. F) and another PMC showed 9 chromosomes at each pole with a laggard (Fig. G). Due to stickiness (Fig. H.) the well spread M-I were difficult to observe. No further meiotic abnormality was observed at any stage of meiosis. The pollen fertility was 87 per cent. The present report confirms many earlier chromosome counts from different parts of India and abroad. Beside present report of $(2 n=18)$, another cytotype with $(22+1-2 B)$ has also been reported from India (Raghuvanshi and Joshi 1968). However, from outside India, diploid, tetraploid and hexaploid cytotypes were also reported (Table 2.).

Thus intraspecific polyploidy on $x=9$ is well represented in the species. In the present study the results show that the nodal explants cultured on MS supplemented with different concentrations and combinations of BAP and Kn have regenerated and gave best response in terms of multiple shoot production. The nodal explants cultured on MS showed signs of bud break in 15 days (Fig. I) followed by production of multiple shoots within 25 - 40 days (Figs J and K). Among two cytokinins, BAP was found to be superior than $\mathrm{Kn}$ in terms of better shoot development and number of shoots per node. The highest percentage of multiple shoot induction was $90.20 \%$ showing an average 16.3 number of shoots on the medium fortified with $2.0 \mathrm{mg} / \mathrm{l} \mathrm{BAP}+0.5 \mathrm{mg} / \mathrm{l} \mathrm{Kn}$ (Graphs 1 and 2), followed by $75.30 \%$ shoot induction and an average of 9.5 shoots in the medium supplemented with $3.0 \mathrm{mg} / \mathrm{l} \mathrm{BAP}+0.5 \mathrm{mg} / \mathrm{l} \mathrm{Kn}$. The individual concentration 3.0 $\mathrm{mg} / \mathrm{l} \mathrm{BAP}$ showed $70.50 \%$ of shoot induction with an average of 4.1 number of shoots, followed by $58.23 \%$ shoot induction with an average of 2.8 shoots in the medium containing $2.0 \mathrm{mg} / \mathrm{l} \mathrm{BAP,}$, whereas, $\mathrm{Kn}$ can also induce $56.75 \%$ shoots and an average of 2.3 shoots per node, when used individually with a concentration of $3.0 \mathrm{mg} / \mathrm{l} \mathrm{Kn}$ (Table 3).

Thus, from the present results BAP was found to be effective and superior for shoot induction if used in combination with Kn (Figs L, M and N). Earlier, it was reported that BAP individually acts as a better agent for shoot induction. These findings are also consistent with the earlier reports on different medicinal plants (Chirangini et al. 2005, Ghanti et al. 2004, Karthikeyan et al. 2007, Lal et al. 1998, Sharma et al. 2014). Well-developed shoots were isolated and cultured on MS having different concentrations of NAA and IBA. The frequency and number of roots per shoot varied with individual and combined concentrations of the NAA and IBA. Among all the concentrations, the combined concentration of $1.0 \mathrm{mg} / \mathrm{l}$ $\mathrm{NAA}+1.0 \mathrm{mg} / \mathrm{l}$ IBA showed highest $92.2 \%$ root induction with an average 16.5 
number of roots per shoot (Graphs 3 and 4), whereas, among all individual concentrations, the highest $83.9 \%$ root induction with average 12.5 number of roots per shoot in the medium containing $2.0 \mathrm{mg} / \mathrm{l} \mathrm{IBA}$ was achieved, followed by $76.2 \%$ root induction with an average 9.5 number of roots per shoot in the medium containing $2.0 \mathrm{mg} / \mathrm{l} \mathrm{NAA}$ (Table 4.).

Table 3. Effect of BAP and Kn on shoot multiplication from the nodal explants of $C$. asiatica on MS.

\begin{tabular}{lccccc}
\hline Sl. No. & $\begin{array}{c}\text { BAP } \\
(\mathrm{mg} / \mathrm{l})\end{array}$ & $\begin{array}{c}\text { Kn } \\
(\mathrm{mg} / \mathrm{l})\end{array}$ & $\begin{array}{c}\text { Mean number } \\
\text { of shoots/ } \\
\text { node }\end{array}$ & $\begin{array}{c}\text { Mean length } \\
\text { of shoots } \\
(\mathrm{cm})\end{array}$ & $\begin{array}{c}\% \text { of } \\
\text { culture } \\
\text { response }\end{array}$ \\
\hline 1. & 1.0 & 0.0 & 1.3 & 1.2 & 33.20 \\
2. & 2.0 & 0.0 & 2.8 & 1.6 & 58.23 \\
3. & 3.0 & 0.0 & 4.1 & 1.9 & 70.52 \\
4. & 0.0 & 1.0 & 1.1 & 2.1 & 26.30 \\
5. & 0.0 & 2.0 & 1.8 & 2.5 & 39.42 \\
6. & 0.0 & 3.0 & 2.3 & 3.1 & 56.75 \\
7. & 1.0 & 0.5 & 6.2 & 2.9 & 65.80 \\
8. & 2.0 & 0.5 & 16.3 & 4.6 & 90.20 \\
9. & 3.0 & 0.5 & 9.5 & 3.4 & 75.30 \\
\hline
\end{tabular}

Table 4. Effect of NAA and IBA on rooting of in vitro raised shoots of Centella on MS.

\begin{tabular}{cccccc}
\hline $\begin{array}{c}\text { Sl. } \\
\text { No. }\end{array}$ & $\begin{array}{c}\text { NAA } \\
(\mathrm{mg} / \mathrm{l})\end{array}$ & $\begin{array}{c}\text { IBA } \\
(\mathrm{mg} / \mathrm{l})\end{array}$ & $\begin{array}{c}\text { Mean number } \\
\text { of roots/shoot }\end{array}$ & $\begin{array}{c}\text { Mean length of } \\
\text { roots }(\mathrm{cm})\end{array}$ & $\begin{array}{c}\text { \% of root } \\
\text { induction }\end{array}$ \\
\hline 1. & 1.0 & 0.0 & 6.3 & 1.2 & 31.5 \\
2. & $\mathbf{2 . 0}$ & $\mathbf{0 . 0}$ & $\mathbf{9 . 5}$ & $\mathbf{2 . 3}$ & $\mathbf{7 6 . 2}$ \\
3. & 3.0 & 0.0 & 4.6 & 1.5 & 34.2 \\
4. & 0.0 & 1.0 & 3.4 & 2.4 & 41.8 \\
5. & $\mathbf{0 . 0}$ & $\mathbf{2 . 0}$ & $\mathbf{1 2 . 5}$ & $\mathbf{6 . 6}$ & $\mathbf{8 3 . 9}$ \\
6. & 0.0 & 3.0 & 5.4 & 3.4 & 54.5 \\
7. & 0.5 & 0.5 & 6.8 & 3.2 & 51.6 \\
8. & $\mathbf{1 . 0}$ & $\mathbf{1 . 0}$ & $\mathbf{1 6 . 5}$ & $\mathbf{6 . 8}$ & $\mathbf{9 2 . 2}$ \\
9. & 1.5 & 1.5 & 6.1 & 3.5 & 56.3 \\
\hline
\end{tabular}

Therefore, it is clear that the combined concentration of $1.0 \mathrm{mg} / \mathrm{l} \mathrm{NAA}+1.0$ $\mathrm{mg} / \mathrm{l} \mathrm{IBA}$ is an ideal treatment for root induction. As we know from the previous reports that IBA was the most suitable auxin for rooting in many plant species (Parveen and Shahzad 2010, Raghu et al. 2006, Shahzad et al. 2007). Again IBA was found to be efficient in inducing rooting in higher altitude Himalayan plants viz., Aconitum atrox (Rawat et al. 1992), Podophyllum hexandrum (Nadeem et al. 2000), Cedrus deodara (Nandi et al. 2002). After 4 weeks, well rooted plantlets 



Fig. 1. Centtella asiatica. A. Plant's bed, B. Shooting and rooting at each node, C. Creeping of long stolons between nodes, D-E. PMC at M-I with 9n, F. PMC at A-I with 9 chromosomes at each pole, G. PMC at A-I showing 9 chromosomes at each pole with laggard, H. PMCs showing stickiness of the chromosomes. I. Nodal explant/shoot tips cultured in MS + BAP. J. Multiple shoots initiation on MS + BAP. K-N. Elongation of in vitro shoots on the medium. O. Acclimatization of in vitro regenerated plants to natural conditions/pot containing sterilized mixture of sand, soil and farmyard manure in the ration of $1: 1: 1($ Scale $=10 \mu \mathrm{m})$. 




Graph 1. Shoot regeneration/induction percentage by using different concentrations of BAP and Kn.

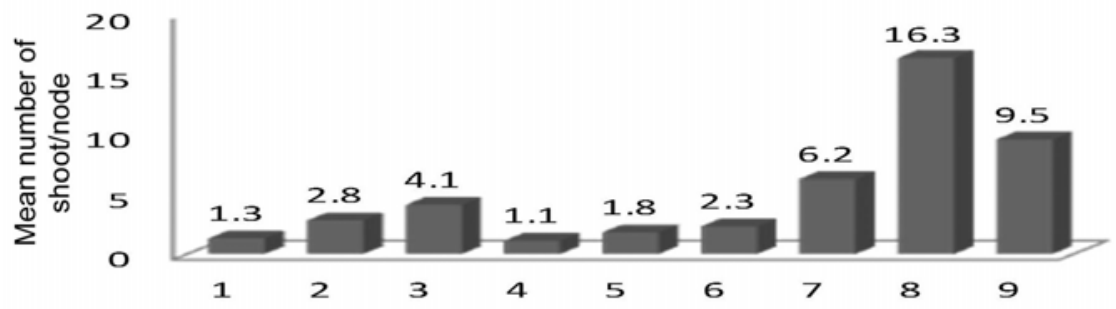

Serial no. of different concentrations of BAP $+\mathrm{Kn}$ for shoot induction

Graph 2. Average/mean number of shoots per node by using different concentration of $\mathrm{BAP}$ and $\mathrm{Kn}$.

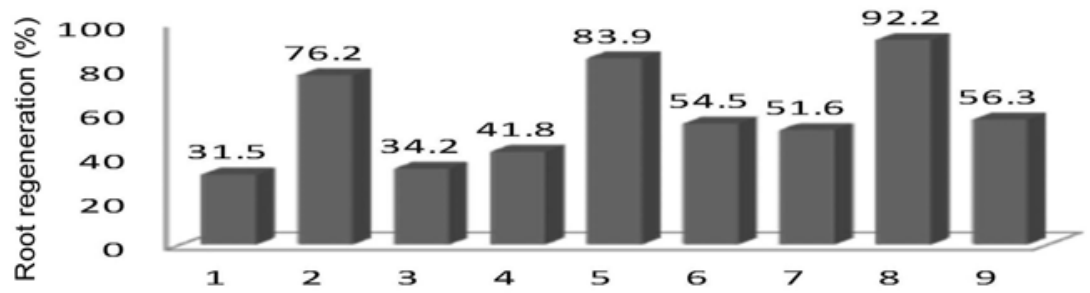

Serial no. of different concentrations of NAA + IBA for root induction

Graph 3. Root regeneration/induction percentage by using different concentrations of NAA and IBA.

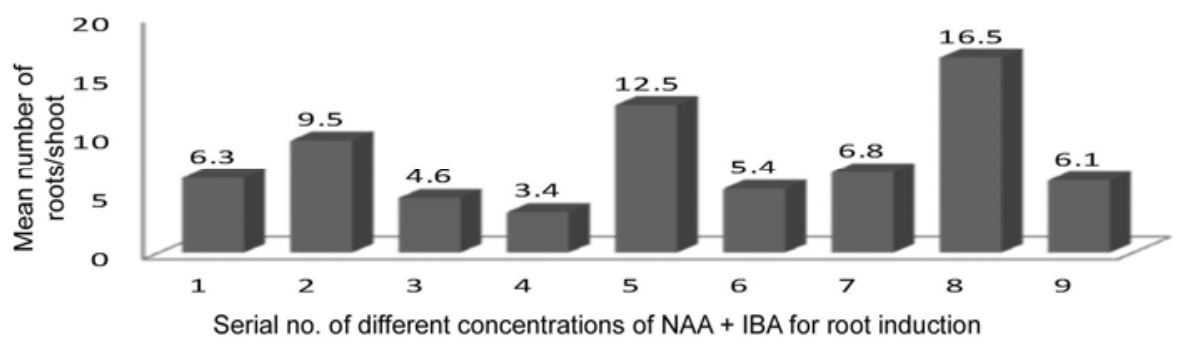

Graph 4. Average/mean number of roots per shoot by using different concentrations of NAA and IBA. 
were obtained and their morphometric characters were studied. These plantlets were removed from the culture vessels, washed gently under running tap water and planted in small pots (plastic cups) containing a potting mixture of sand, soil and farmyard in the ratio of $1: 1: 1$ (Fig. 1O). The potted plantlets were covered by transparent polythene sheet to maintain suitable humidity. After proper acclimation, the survival rate of these plantlets under greenhouse condition was $80 \%$. It has been already reported that the nodal explants are the best source for multiple shoot induction in medicinal plants viz., Rauwolfia serpentina, Vitex negundo, Emblica officinalis (Roy et al. 1995; Vadawale et al. 2006; Rahaman et al. 1999). A number of medicinal plants were also cultured for conservation and multiplication by using various tissue culture techniques viz., Heracleum candicans, Plumbago zealanica, Cassia alata, Solanum trilobatum, Eclipta alba, Ocimum sanctum, Bacopa monniera, Solanum nigrum etc., (Wakhlu and Sharma 1998, Chaplot et al. 2006, Hasan et al. 2008, Jawahar et al. 2004, Tiwari et al. 1998, Vijayakumar et al. 2010, Preethi et al. 2011, Lim et al. 2009, Baskaran and Jayabalan et al. 2005, Sridhar and Naidu 2011).

The above protocol can be exploited for commercial propagation and conservation of valuable medicinal plants which are considered as endangered, endemic and threatened herbs.

In the present report, we have improved the protocol and optimized the combinations for better and superior shoot and root induction in C. asiatica (L.) Urban. The nodal explant culture technique and micropropagation reported here offer an effective method of multiplication and conservation of this important medicinal plant species. Cytomorphological studies play a great role in understanding and evaluating the processes as to how some plant species create new cyto- and morphotype providing material for future research involving this potential medicinal herb.

\section{Acknowledgement}

The authors are grateful to His Holiness Baba Iqbal Singh Ji, President, The Kalgidhar Trust \& Founder Chancellor of Eternal University (H.P.); Hon'ble Vice Chancellor, Eternal University, Baru Sahib (H. P.) India; Hon'ble Vice Chancellor, Guru Granth Sahib World University, Fatehgarh Sahib, the Punjab, India and Head, the Department of Botany, Punjabi University, Patiala (Punjab) India for providing necessary facilities and logistic support for carrying out the study. 


\section{References}

Ahmad I and Koul AK (1980) In IOPB chromosome number reports LXVIII. Taxon. 29: 543.

Anonymous (1992) Wealth of India, Raw Materials, CSIR, New Delhi. 2: 48.

Babu TD, Kuttan G and Padikkala J (1995) Cytotoxic and anti-tumour properties of certain taxa of Umbelliferae with special reference to Centella asiatica (L.) Urban. J. Ethnopharmacol. 48(1): 53-57.

Bakhru HK (2003) Herbs, that heals natural remedies for good health, Orient Paperbacks, Delhi, pp. 112-115.

Banerjee S, Zehra M and Kumar S (1999) In vitro multiplication of Centella asiatica, a medicinal herb from leaf explants. Curr. Sci. 76: 110-112.

Baskaran and Jayabalan (2005) An efficient micropropagation system for Eclipta alba- A valuable medicinal herb. In vitro Cell Dev. Biol. Plant. 41: 532-539.

Bibi Y, Zia M, Nisa S, Habib D, Waheed A and Chaudhary FM (2011) Regeneration of Centella asiatica plants from non-embryogenic cell lines and evaluation of antibacterial and antifungal properties of regenerated calli and plants. J. Biol. Engg. 5(13): 1-8.

Brinkhaus B, Lindner M, Schuppan D and Ilahn EG (2000) Chemical, pharmalogical and clinical profile of the East Asian medical plant Centella asiatica. Phytomed. 7(5): 427428.

Cesarone MR, Laurora G, De Sanctis MT and Belcaro G (1992) Activity of Centella asiatica in venous insufficiency. Minerva Cardioangio. 140:137-43.

Chakraborty T, Sinha BS and Sukul NC (1996) Preliminary evidences of antifilarial effects of Centella asiatica on canine dirofilariasis. Fitoterap. 67: 110-112.

Chaplot BB, Dave AM and Jasrai YT (2006) A valuable medicinal plant- Chitrak (Plumbago zeylanicum L.): Successful plant regeneration through various explants and field performance. Plant Tissu. Cult. Biotechnol. 16(2): 77-84.

Chaturvedi P, Joshi K and Shubhpriya (2013) Efficient in vitro regeneration protocol of Centella asiatica (L.) Urban: An endemic and underutilized nutraceutical herb. Afr. J. Biotech. 12(33): 5164-5172.

Chirangini P, Sinha SK and Sharma GJ (2005) In vitro propagation and microrhizome induction in Kaempferia galangal Linn. and K. rotunda Linn. Ind. J. Biotechnol. 4:404408.

Darnis F, Orcel L, de Saint-Maur PP and Mamou P (1979) Use of a titrated extract of Centella asiatica in chronic hepatic disorders. Sem. Hop. 55(37-38): 1749-1750.

Das A and Mallick R (1991) Correlation between genomic diversity and asiaticoside content in Centella asiatica (L.) Urban. Bot. Bull. Acad. Sin. 32: 1-8.

Datta and Maiti RK (1968a) Chromosomal biotypes of Adhatoda vasica Nees growing in Eastern Part of India. Cytologia. 33: 220-229.

Datta and Maiti (1968b) Chromosomal biotypes of Centella asiatica (Linn.) Urban and Hydrocotyle javanica Thunb. Nucleus. 11: 111-117.

Ghanti K, Kaviraj CP, Venugopal RB, Jabeen FTZ and Rao S (2004) Rapid regeneration of Mentha piperita L. from shoot tip and nodal explants. Ind. J. Biotechnol. 3: 594-598. 
Hamal IA and Koul AK (1989). Taxonomic position of Centella asiatica (L.) Urban. Proc. Indian Acad. Sci. Pl. Sci. 99: 363-368.

Hanida SS and Kapoor VK (1988) Pharmacognosy. Vallabh Prakashhan Educational Publishers, Delhi.

Hasan MF, Das R, Rahman MS, Hossain MS and Rahman M (2008) Micropropagation from shoot tips and nodal segments of Cassia alata L. Intl. J. Bio. Res. 4(4): 70-74.

Hausen BM (1993) Centella asiatica (Indian Pennywort), an Effective Therapeutic but a Weak Sensitizer. Contact Dermatitis. 29(4): 175-79.

Herbert D, Paramasivan CN, Prabhakar R and Swaminanthan G (1994) In-vitro experiments with Centella asiatica, investigation to elucidate the effect of an indigenously prepared powder of this plant on the acid-fastness and viability of Mycobacterium tuberculosis. Indian J. Lepr. 66: 65-68.

Hossain SN, Rahman S, Joydhar A, Islam S and Hossain M (2000) In vitro propagation of Thankuni (Centella asiatica L.). Plant Tissue Cult. 10(1): 17-23.

Huq AM (1986) Plant names of Bangladesh (Native and Scientific). Bangladesh National Herbarium (BARC), 229, Green Road, Dhanmondi, Dhaka. pp. 26.

Inamdar PK., Yeole RD, Ghogare AB and de Souza NJ (1996) Determination of biologically active constituents in Centella asiatica. J. Chromatogr. A. 742(1-2): 127-30.

Jawahar M, Rebert GA and Jeyaseelan M (2004) Rapid proliferation of multiple shoots in Solanum trilobatum L. Plant Tissue Cult. 14(2): 107-112.

Jorge OA and Jorge AD (2005) Hepatotoxicity associated with the ingestion of Centella asiatica. Revista Espanola De Enfermeda des Digestivas. 97(2): 115-124.

Joshi S and Raghuvanshi SS (1970) B chromosomes in Centella asiatica. Genetica Iberia. 22: 161-162.

Karthikeyan K, Chandran C and Kulothungan S (2007). Rapid regeneration of Phyllanthus niruri L. from shoot tip and nodal explants. Ind. J. Appl. Pure Biol. 22: 337342.

Karthikeyan K., Chandran C and Kulothungan S (2009) Rapid clonal multiplication through in vitro axillary shoot proliferation of Centella asiatica L. Indian J. of Biotechnol. 8(2): 232-235.

Kirtikar KR and Basu BD (1975). Indian medicinal plants. II Edition. M/s Bishen Singh Mahendra Pal Singh, New Delhi.

Krishnappa DG and Basappa AN (1988) SOCGI Plant Chromosome Number Reports VI. J. Cytol. Genet. 23: 38-52.

Kumar V and Subramaniam B (1986) Chromosome Atlas of Flowering Plants of the Indian Subcontinent. Vol. I. Dicotyledons. Bot. Survey. India, Calcutta.

Lal N, Ahuja PS, Kukreja AK and Pandey B (1998) Clonal propagation of Picrorhiza kurroa Royle ex Benth. By shoot tip culture. Plant Cell Rep. 7: 201-205.

Lim ZX, Ling APK and Hussein S (2009) Callus induction of Ocimum sanctum and estimation of its total flavonoids content. Asian J. Agric. Sci. 1: 55-61.

Love A and Love D (1975) In: IOPB Chromosome Number Reports XLVIII. Taxon 24: 367372. 
In vitro Micropropagation and Cytomorphological Evaluation

Martin KP (2004) Plant regeneration through somatic embryogenesis in medicinally important Centella asiatica L. In vitro Cell Dev. Biol. Plant. 40: 586-591.

Mitra K and Datta N (1967) In: IOPB Chromosome Number Reports XIII. Taxon 16: 445461.

Moghaddam SS, Jaafar HB, Aziz MA, Ibrahim R, Rahmat AB and Philip E (2011) Optimization of an efficient semisolid culture protocol for sterilization and plant regeneration of Centella asiatica (L.) as a medicinal herb. Molecule. 16: 8981-8991.

Montecchio GP, Samaden A, Carbone S, Vigotti M, Siragusa S and Piovella F (1991) Centella asiatica triterpenic fraction (CATTF) reduces the number of circulating endothelial cells in subjects with post phlebitis syndrome, Haematologica.76(3), 256259.

Nadeem M, Palni LMS, Purohit AN, Pandey H and Nandi SK (2000) Propagation and conservation of Podophyllum hexandrum Royle: an important medicinal herb. Biol. Consev. 92:121-129.

Naidu CV, Panathula CS and Mahadev MD (2014) High efficiency adventitious indirect organogenesis and plant regeneration from callus of Centella asiatica (L.) -An important Antijaundice medicinal plant. Intl J of Adv. Res. 2(1): 1027-1036.

Nandi SK, Tamta S and Palni LMS (2002) Adventitious root formation in young shoots of Cedrus deodara L. Plant Biol. 45: 47, 2002.

Nath S and Alak KB (2003) In vitro method for propagation of Centella asiatica (L) Lucas Urban by shoot tip culture. J. Plant Biochem. Biotechnol. 12: 167-169.

Nayar MP and Sastry ARK (1987) Red data book of Indian plants. Vol. 1. Botanical Survey of India, Howrah. pp. 23.

Nayar MP (1996) 'Hotspots' of endemic plants of India, Nepal and Bhutan (Tropical Botanical Garden and Research Institute), Thiruvanthapuram. pp. 1-220.

Pandey NK, Tewai KC, Tewari RN, Joshi GC, Pande VN and Pandey G (1993) Medicinal plants of Kumaon Himalaya, strategies for conservation. In: Dhar U (ed) Himalayan Biodiversity Conservation Strategies, No. 3 (pp. 293-302). Himavikas Publication, Nanital.

Parveen S and Shahzad A (2010) TDZ induced high frequency shoot regeneration in Cassia sophera L. via cotyledonary nodal explants. Physiol. Mol. Bio. Plants. 16: 201206.

Patil KS and Mandewgade SD (2003) Wound healing activity of leaves of Lawsonia alba. J. Nat. Remedies. 3: 129-133.

Patra A, Rai B, Rout GR and Das P (1998) Successful regeneration from callus cultures of Centella asiatica (L.) Urban. Plant Growth Regul. 24: 13-16.

Prakash ES, Valli K, Sairam PS, Reddy P and Rao KR (1999) Regeneration of Plants from seed-derived callus of Hybanthus enneaspermus L. Muell.- a rare ethnobotanical herb. Plant Cell Rep. 18: 873-878.

Prasad NP and Janakiammal EK (1985) Chromosome Count of Centella asiatica (Linn.) Urban. Curr. Sci. 54: 706-707. 
Preethi D, Sridhar TM and Naidu CV (2011) Efficient protocol for indirect shoot regeneration from leaf explants of Stevia rebaudiana (Bert.) - An important calorie free biosweetner. J. Phytology. 3(5): 56-60.

Pullaiah T (2006) Encyclopaedia of World Medicinal Plants. Vol. I-V. Regency Publisher, New Delhi, pp. 2442.

Raghu AV, Geetha SP, Martin G, Balachandran I and Ravindran PN (2006) Direct shoot organogenesis from leaf explants of Embelica ribes Burm. F: a vulnerable medicinal plant. J. Forest Res. 11: 57-60.

Raghuvanshi SS and Joshi S (1968) Accessories in certain plants. Nucleus, Suppl. Vol. 1968: 319-323.

Rahaman MM, Roy PK, Mannan MA and Roy SK (1999) Clonal propagation of Emblica officinalis through in vitro culture. Plant Cell Tissue Organ Cult. 9: 17-12

Rahman MR, Das MF, Hasan MS and Hossain (2008) Micropropagation of Centella asiatica L. An Important Medicinal Herb. Progress Agric. 19(2): 51-56.

Rawat AS, Pharswan AS and Nautiyal MC (1992) Propagation of Aconitum atrox (Bruhl) Muk.(Ranunculaceae); a regionally threatened medicinal herb. Con. Bot. 46: 337-338.

Rao NK (2004) Plant genetic resources: Advancing conservation and use through biotechnology. Afr. Biotechno. 13: 136-145.

Roy SK, Roy PK, Rahaman M and Hossain (1995) Clonal propagation of Rauwolfia serpentine through in vitro culture. Acta Hortic. 390: 141-145.

Sahoo Y and Chand PK (1998) Micropropagation of Vitex negundo L.- a woody aromatic medicinal shrub through high frequency of axillary shoot proliferation. Plant Cell Rep. 18: P.301-307.

Satake T, KamiyakAn Y, Oishi NTT and Yamamoto J (2007) The anti-thrombic active constituents of Centella asiatica. Pharm. Bull. 30: 5-940.

Shahzad A, Farsal M and Anis M (2007) Micropropagation through excised shoot culture of Clitoria ternatea and comparison between In vitro regenerated plants and seedlings. Ann. Appl. Biol. 150: 341-349.

Sharma BL and Kumar A (1998) Biodiversity of medicinal plants of Triyugi Narain (Garhwal Himalaya) and their conservation. National conference on recent trends in Spices and medicinal plants Research, Calcutta, WB, India. pp. 78.

Sharma R, Acharjee S and Kumar SB (2014) An efficient In vitro regeneration system in lentil (Lens culinaris) using cotyledons with half embryonic axes. Res. J. Biotech. 9(1): 9-15.

Shukla A, Rasik AM, Jain GK, Shankar R and Kulshrestha D (1999b) In vitro and in-vivo wound healing activity of asiaticoside isolated from Centella asiatica. J. Ethnopharmacol. 65(1):1-11.

Silviya RJ (2010) Enhancement of memory in rats with Centella asiatica. Biomed. Res. 21(4): 429-432.

Singh HG (1989) Himalayan herbs and drug importance and extinction threat. J. Med. Aromat. Plant Sci. 19: 1049-1056.

Sinha BMB and Sinha AK (1978) The chromosomes of certain species of the Umbelliferae. The Botanique. 8: 117-122. 
Sridhar TM, Preethi D and Naidu CV (2011) Effect of silver thiosulphate on in vitro plant regeneration of Solanum nigrum (L.)- An important antiulcer medicinal plant. Curr. Bot. 2(7): 14-16.

Srivastava R, Shukla YN and Kumar S (1997) Chemistry and pharmacology of Centella asiatica: a review. J. Med. Aromatic Plant Sci. 19: 1049-1056.

Subramanian (1986) Cytotaxonomical studies in South Indian Apiaceae. Cytologia. 51: $479-488$.

Sudha SS, Kumaresan A, David AJ and Venkataraman BV (2002) Anti-convulsant activity of different extracts of Centella asiatica and Bacopa monnieri in animals. J. Nat. Remedies. 2(1): 33-41.

Tiwari V, Singh BD and Tiwari KN (1998) Shoot regeneration and somatic embryogenesis from different explants of Brahmi (Bacopa monniera (L.) Wettst.). Plant Cell Rep. 17: 538-543.

Tiwari KN, Sharma NC, Tiwari V and Singh BD (2000) Micropropagation of Centella asiatica (L.), a valuable medicinal herb. Plant Cell Tiss. \& Org. 63: 179-185.

Tolkha NM (1999) Genetic variation of Centella asiatica based on randomly amplified polymorphic DNA. Ethnobot. J. 22: 7-13.

Trivedi MP and Trivedi RN (1992) Chromosomal behaviour in weeds. Glimpses Cytogenet. India. 3: 188-198.

Vadawale AV, Barve DM and Dave AM (2006) In vitro flowering and rapid propagation of Vitex negundo L. - A medicinal plant. Indian J. Biotechnol. 5:112-116.

Vasantharuba S, Banumathi P, Premalatha MR, Sundaram SP and Arumugam T (2012) Functional properties of Centella asiatica (L.): A review. Int. J. Pharm. Pharm. Sci. 4: 814.

Vijayakumar M, Vijayakumar R and Stephen R (2010) In vitro propagation of Bacopa monnieri (L.) - a multipurpose medicinal plant. Int. J. of Sci. \& Tech. 3(7): 781-786.

Wakhlu AK and Sharma RK. (1998) Micropropagation of Heracleum candicans Wall: A rare medicinal herb. In vitro Cell Dev. Biol. Plant. 35: 79-81.

Warrier PK, Nambiar VPK and Ramankutty C (1994) Indian medicinal plants. A compendium of 500 species. Volume 1, Orien Longman Pvt. Ltd., Madras, India. pp. 52-55.

Yen GC, Chen HY and Peng HH (2001) Evaluation of the cytotoxicity, mutagenicity and antimutagenicity of emerging edible plants. Food Chemical Toxicol. 39: 1045-1053.

Yoshida M, Fuchigami M, Nagao T, Okabe H, Matsunaga K, Takata, Karube $\mathrm{Y}$ and Fujioka T (2005) Antiproliferative constituents from Umbelliferae plants VII. Active triterpenes and rosemarinic acid from Centella asiatica. Biol. Pharma. Bull. 28: 173-175.

Yu QL, Duan HQ, Takaishi Y and Gao WY (2006) A novel triterpene from Centella asiatica. Molecules. 11: 661-665.

Zheng CJ and Quin LP (2007) Chemical component of Centella asiatica and their bioactivities. Chinese J. Integrative Med. Eds. Zhong Xi, Yi Jie, and Xue Bao. 5: 348351. 